\title{
Quality Assurance Frameworks Comparisons in HEIs of Pakistan and China
}

\author{
Urooj Fatima \\ Zhang Junchao
}

University of Science and Technology, School of Education, China

\section{Daniyal Khan}

Karachi Institute of Economics and Technology, Management Sciences, Pakistan

Doi:10.19044/ejes.v7no2a2 URL:http://dx.doi.org/10.19044/ejes.v7no2a2

\begin{abstract}
The Higher Education Commission in Pakistan and China is are responsible to check that all educational institutes of Pakistan-comply with the Quality Assurance Framework (QAF). Work distribution, access to the digital library and the number of $\mathrm{PhD}$ faculty members in the institutes, are important for Higher Educational Institutes (HEIs) because they directly influence on quality of academic education and services being provided to the students. Mixed method approach is adopted. Quantitative results were obtained by carrying out survey in Pakistan while qualitative results were obtained through literature review. This research makes use of quantitative approach and investigates four different HEIs of Pakistan. The questionnaire was divided into three sections: 1) Role of work distribution; 2) access to the digital library; and 3 ) the number of Faculty members in the PhD faculty. A critical review was carried out for investigating the quality of HEIs in China because survey accessibility issues were faced when adopting quantitative approach. Analysis showed that most of the QAFs in Pakistan were weak in all three factors. Yet China had a better score when compared to Pakistan showing good work distribution; high number of digital libraries; and an adequate number of $\mathrm{PhD}$ faculty members.
\end{abstract}

Keywords: Higher Educational Institutes, Pakistan, China work distribution, access to digital library, number of $\mathrm{PhD}$ faculty. 


\section{Introduction}

The Quality Assurance Parameters (QAPs) in the Higher Education Institutes (HEIs) are considered the base for growth within the education sector, for promoting quality education and sustaining the satisfaction level of the students. People living in different areas of Pakistan have complained that their education standards are not improving and challenges related to improving the quality assurance frameworks in educational institutes is in need of improvement. Nations such as China has improved its education system and are thereby able to attract international students from every nation. Although a number of parameters can be included in under QAPs, this paper investigates three of them, 1) Role of work distribution; 2) access to the digital library; and 3) the number of Faculty members in the $\mathrm{PhD}$ faculty working in different educational institutes of Pakistan. A critical review of the educational institutes in China was carried out for comparison with Pakistan.

The Higher Education Commission (HEC) in Pakistan is the governing body of educational institutes in Pakistan that aims to govern the responsibilities in this corporate sector by organising and improving various parameters within the education sector. Aslam (2018) argued that educational institutes of Pakistan heavily rely on equal distribution of workload in all the educational institutes of Pakistan because it significantly allows the management to focus on growth and increase the efficiency in the operations. It has been observed by Sukdee, Tornee and Kraiptech (2017), that HEC developed Quality Enhancement Cells (QECs), work for the development of educational institutes by monitoring the work distribution in educational institute of Pakistan (Shabbir et al., 2016).

The governance of HEIs in China is done by the State and local Councils, which monitors the facilities provided in each department. According to Liu, Hu and Huang (2019), the HEIs in China focus on many parameters in improving quality of education and some of them include, quality of work distribution, and increasing accessibility for the students. Bhayo et al., (2018) reported that the number of PhD faculty members in China have increased in the order of thousands in the last 10 years because of the special focus on increasing the quality of their classroom environment.

These QEC's developed many parameters for checking the work distribution and some of them include distribution of the workload by individually checking working hours of the staff members. Shaikh, Memon and Shah (2017) argued that some professionals in Pakistan work long hours, while some of them leave early, which depicts an unequal work distribution. In the majority of educational institutes in Pakistan, it has been observed that most of the people in HEIs of Pakistan are working hard to improve the quality of education including the HEC, but the management of HEC is unwilling to make changes in some universities (Shabbir et al., 2016). Aslam (2016) found 
that most of the educational institutes of Punjab, critically suffered from the problems of distributing the workload due to the low working attitude and high interference of teachers. Therefore, it has become important for the management of HEC to incorporate new changes in the management of issues so that challenges can be incorporated in terms of elevating education standards.

Another parameter which is under investigation by Sukdee, Tornee and Kraiptech (2017), is student access to the digital library Each university management is now forcing the IT professionals to develop an online portal, where student access to their digital library is available. Research by Bhayo et al., (2018) and Liu, et al., (2019) found that universities have now started to give students access to their digital library because it creates an environment of researching and opportunities to learn the concepts of new research techniques. This paper examines Pakistani and Chinese universities not using the online portal for the development of new and improved learning atmosphere to improve quality in HEIs.

The last factor under investigation in this study is the number of $\mathrm{PhD}$ teachers working in educational institutes of Pakistan and China. According to Herani, Mugheri and Advani (2015), if the number of $\mathrm{PhD}$ teachers in a university is high, it becomes easier for the management of that educational institute to elevate quality of higher education and increase positive reviews of the students for their teachers. Since the development of HEC in Pakistan, it has been observed that top management has set criteria each university has to follow in terms of the minimum number of $\mathrm{PhD}$ teachers-an educational institute must contain (Herani, Mugheri \& Advani, 2015). While in China, $\mathrm{PhD}$ faculty members are hired from international universities so that best people can be on staff. Not many studies have tried to carry out comparative analysis on these quality parameters in educational institute of Pakistan and China therefore, this study could make a significant contributions to the limited literature in this area.

Pakistan's education standard is rising-because the management of HEC has started to focus on the management of quality parameters by raising the number of quality factors in the institutes, to make the education department of Pakistan sustainable and meeting the international standards. Mohsin, Mohsin and Rasheed (2016) supported the statement that not many educational institutes in the Pakistan HE sector are focusing on equal work distribution nor making the changes in workflow. Due to this reason, it is important to evaluate the reasons behind this lack of focus on workload management in educational institutes.

The quality of educational institutes in China depends upon the facilities they provide to their students, in order to improve quality of education and to increase their interest in scientific research. According to 
Bhayo et al., (2018) student access to a digital library is also considered necessary, because it elevates the education standards, and it is the responsibility of educational institutes management in China to check whether students have access to the digital library through an online portal. Only a few studies were found on the internet in China which investigated, whether universities are providing access to digital library (Sukdee, Tornee \& Kraiptech 2017; Viraiyan, Kamalanabhan \& Keshwar, 2016). Therefore, this paper investigates, whether educational institutes are providing the required support to their students through access to their digital library.

Shabbir et al., (2016) reported that only a few educational institutes have started to hire the adequate number of $\mathrm{PhD}$ teachers, which highlights a major research gap in Pakistan. It has been observed that $\mathrm{PhD}$ teachers in educational institutes of Pakistan have started to focus on the development of new and improved changes, which include hiring of $\mathrm{PhD}$ teachers (Herani, Mugheri \& Advani, 2015). However, this is quite challenging for small institutes, as they do not have the required revenues to meet salary expenses of these PhD teachers. Gao et al., (2019) reported that in China many PhD teachers were recently hired with a starting salary of a 100k Dollars per month on average (Zhou, 2019).

\section{Review of literature}

Shaikh, et.al., (2017) argued that the quality of educational institutes in Pakistan depends upon a number of parameters and one of them is the role of equal work distribution in educational institutes. They found that $50 \%$ of educational institutions or less are following the rule of equal work distribution. Aslam (2016) wrote that a collaborative working environment is a proven method for producing stronger academic achievement, and it is very challenging for HEIs to implement them. Some of them do not have adequate resources, while some of them are unwilling to implement it. Therefore, it is important to look into the educational institutes' performances and their willingness to divide the work equally among their workers.

In studies presented in this paragraph, it is believed that equal work distribution is not possible in educational institutes because it creates challenges for the management to individually check performance of each professional (Shahid, Wahab \& Ahmed; 2016; Sukdee, Tornee \& Kraiptech, 2017). Shahid, Wahab and Ahmed (2016) found that people working in educational institutes were not willing to divide their work role due to laziness. Additionally, university management was not having the required resources and tools for checking and building a new working environment. Sukdee, Tornee and Kraiptech (2017) wrote that it was due to the poor role played by the Commission. That they only evaluated the work role distribution in big educational institutes of Pakistan, whilst smaller institutes remained 
unchecked. Therefore, it is important to identify the need of carrying out a check and balance on the activities, because it is a difficult task for the HEC to go and check work distribution in each educational institute.

Another parameter included in the QAF produced by HEC, was student is access to a digital library. According to Hazelkorn, Coates and McCormick (2018), it is the responsibility of management to ensure that each student is provided with access to digital library and supported with latest editions of book and scholarly articles for making research easier for them. Khan and Kamran (2017) added that access to digital library was necessary for students because it improved their researching skills and elevated their interest in reading. However, Sukdee, Tornee and Kraiptech (2017) wrote that not many educational institutes focussed on the development of digital library access, and most students faced issues in carrying out their research. Therefore, it is important to elevate the performance of the graduates by increasing their researching capabilities and improving their writing abilities.

It has been observed that digital libraries play a crucial part in lifting the education level of a university (Viraiyan, Kamalanabhan, \& Keshwar, 2016; Hina and Ajmal, 2016). Students can easily access their textbooks online and access them without physically going to a university library. Viraiyan, Kamalanabhan and Keshwar (2016) wrote that this increases quality of education because the management of the educational institute can restrict students to deadlines and reduce unnecessary excuses for not completing their assignments or research reports. However, Hina and Ajmal (2016) reported that universities did not possess the required expertise through which they could develop an internet portal and produce the desired results for the management. Hence it is necessary for the management to hire professional software engineers who can work on professional software packages to create an online portal.

An educational institute should focus on hiring of PhD faculty as much as it can, because it can allow the management to increase quality of classroom environment and ultimately the learning among the students (Hina \& Ajmal, 2016; Baig, Abrar Ali \& Ahmed, 2015). In Pakistan, the management of HEC understands this, and recently it introduced new challenges for the development of educational institutes, which includes a minimum number of PhD faculty members to be hired by the educational institutes. However, ranking of Pakistani institutes shows that not many $\mathrm{PhD}$ teachers might be present in the institutes, due to the low focus of management as reported by Hina and Ajmal (2016). Ajmal (2017) wrote that low number of PhD faculty members in educational institutes of Pakistan was due to the fact that most universities could not afford them. Furthermore, it was observed that most students undertook their PhD degree from outside of Pakistan due to the shortage of $\mathrm{PhD}$ graduates in Pakistani universities (Baig, Abrar Ali \& 
Ahmed, 2015). Hence, it can be argued that most of the educational institutes should be given the support by the management of HEC, so they can focus on increasing the investment on $\mathrm{PhD}$ faculty, and can improve quality of academic education.

Studies by Pornphol and Chittayasothorn (2017) and John and Fanghanel (2015) explored the context of other educational institutes located outside of Pakistan. Pornphol and Chittayasothorn's (2017) research was based on new developments in educational institutes of Qatar. They reported that educational institutes in Qatar have started to report on the development of new educational institutes, which contain $50 \%$ of $\mathrm{PhD}$ faculty members. According to their results, the value of graduates in Qatar had doubled in the last decade, due to these small changes they gave on the development of educational institutes. John and Fanghanel (2015) reported that if $\mathrm{PhD}$ faculty members were hired by the educational institutes that quality of education will definitely improve. PhD level teachers challenge their students by using their personal experience and challenge their students to think out of the box (John \& Fanghanel, 2015). Therefore, it is the responsibility of university management to ensure that at least $50 \%$ of the faculty members have studied to $\mathrm{PhD}$ level in their education.

\section{Literature gap}

There is not a single investigation which evaluates the quality level of the educational institutes in both Pakistan and China. Subhani, Osman and Niaz (2017) argued that there is a need to reduce the quality gap among educational institutes of Pakistan because no study was found analysing all the three parameters. This study will investigate all these three parameters by observing their importance in universities. Since no investigation has been carried out on a similar topic in the last five years, it is hard to predict the quality of academic education based on these three parameters. It is important to evaluate; whether quality parameters produced by HEIs in both China and Pakistan for elevating academic quality through these three variables are producing desired results or not.

\section{Hypotheses}

Based on the investigations made in the literature review above, this research paper investigates the following hypotheses:

$\mathrm{H} 1$ - Role of work distribution in improving quality education is low in Higher Educational Institutes (HEIs) of Pakistan as compared to China.

$\mathrm{H} 2$ - Access to digital library in improving quality education is low in HEIs of Pakistan as compared to China. 
$\mathrm{H} 3$ - Number of $\mathrm{PhD}$ faculty members in educational institutes of Pakistan is low as compared to China and contributing to low quality among the educational institutes.

\section{Research question}

Based on the above literature review, this research works on the following questions:

1. What is the role of work distribution in improving quality education in HEIs of Pakistan and China?

2. Do the students are provided with access to digital libraries in HEIs of Pakistan and China?

3. Is the number of $\mathrm{PhD}$ faculty members in HEIs of China are more as compared to Pakistan?

\section{Methods}

This study analysed the findings through quantitative methodology, specifically using survey methodology and developed a questionnaire based on 5-point Likert scale methodology (Kumar, 2019). Data collection in China was collected through a critical literature review approach (Kumar, 2019). The reason to select this approach was because physical data in China was difficult to obtain. In addition, data related to China was readily available on internet which made it easier for the investigator to collect and compare it. The questionnaire was distributed online and was segmented into 3 three sections, namely work distribution, student access to a digital library, and the number of $\mathrm{PhD}$ faculty members in educational institutes of Pakistan. The data were collected from 200 students from four different universities of Pakistan, namely Pakistan Air Force- Karachi Institute of Economics and Technology (PAF-KIET), FAST University, Karachi, Iqra University (IU), Karachi and Government College University (GC), Faisalabad. The questionnaire comprised of nine questions in total (three in each section), and the data were analysed on SPSS Version 21.

The 5-point Likert scale questionnaire comprised of five options: strongly agree, agree, neutral, disagree and strongly disagree. The students were enrolled in the Bachelors, Masters and $\mathrm{PhD}$ degree programs in engineering and management fields Research of their respective universities. The hypothesis was accepted if the percentage of 'strongly agree' or 'agree' parenthesis needed was more than strongly disagreed and disagreed. Some ethical considerations were also undertaken in the investigation. E.g. only the students willing to participate in the survey were selected for the investigation. In addition, students who completely filled the questionnaire were analysed in the results of the next section. 


\section{Results and discussion}

After carrying out the investigation in this study, it is necessary to segment the results comprehensively by presenting the results in an appropriate form. This research made use of SPSS 21.0 software for running the validity and reliability analysis once collecting the results through the questionnaire. The value of Cronbach Alpha came out to be 0.889, indicating that data collected has good reliability. In addition, the value of KOM was also observed to be 0.772 which lies between 0.7 and 0.8 , and indicating that questionnaire was valid.

\section{Work distribution in HEIs of Pakistan (first hypothesis)}

The first statement of the questionnaire can be observed below:

- The work role distribution in different departments of Higher Educational Institutes is not done adequately.

The results were obtained in the following fashion:

Table 1 Statement 1 results Statement 1

\begin{tabular}{|c|c|c|c|c|c|}
\hline & & Frequency & Percent & $\begin{array}{l}\text { Valid } \\
\text { Percent }\end{array}$ & $\begin{array}{l}\text { Cumulative } \\
\text { Percent }\end{array}$ \\
\hline \multirow{7}{*}{ Valid } & Strongly Agree & 89 & 44.5 & 44.5 & 44.5 \\
\hline & Agree & 72 & 36.0 & 36.0 & 80.5 \\
\hline & Neutral & 8 & 4.0 & 4.0 & 84.5 \\
\hline & Disagree & 21 & 10.5 & 10.5 & 95.0 \\
\hline & Strongly & 10 & 5.0 & 5.0 & 100.0 \\
\hline & Disagree & & & & \\
\hline & Total & 200 & 100.0 & 100.0 & \\
\hline
\end{tabular}

The results show that most of the students were not satisfied with the work role distribution in different departments of their educational institutes. Of the 200 candidates, $44.5 \%$ strongly agreed, $36 \%$ agreed, $4 \%$ remained neutral, $10.5 \%$ disagreed and $5 \%$ strongly disagreed. Based on these findings, the management of these educational institutes needs to focus on equal work distribution, since the students believe that it is not done in an adequate manner.

- There is an important role of equal work distribution in improving quality education in educational institutes of Pakistan. 
Table 2 statement 2 results

Statement 2

\begin{tabular}{|l|l|l|l|l|}
\hline & Frequency & Percent & $\begin{array}{l}\text { Valid } \\
\text { Percent }\end{array}$ & $\begin{array}{l}\text { Cumulative } \\
\text { Percent }\end{array}$ \\
\hline Strongly Agree & 87 & 43.5 & 43.5 & 43.5 \\
Agree & 67 & 33.5 & 33.5 & 77.0 \\
Neutral & 8 & 4.0 & 4.0 & 81.0 \\
Valid & 25 & 12.5 & 12.5 & 93.5 \\
Disagree & 13 & 6.5 & 6.5 & 100.0 \\
Strongly & & & & \\
Disagree & 200 & 100.0 & 100.0 & \\
Total & &
\end{tabular}

The observations made in the questionnaire showed that the majority of the respondents rated equal work distribution as an important factor in improving quality education in educational institutes. $43.5 \%$ strongly disagree, $33.5 \%$ agree, $4.0 \%$ remained neutral, $12.5 \%$ disagreed while $6.5 \%$ strongly disagreed. Based on these observations made, it can be said that the management of the four institutes needs to focus on equal workload distribution to elevate quality education in the educational institutes.

The third statement in the first part of the questionnaire was:

- It is considered necessary to divide work equally in order to improve quality of education in HEIs.

Table 3 Statement 3 results

Statement 3

\begin{tabular}{|l|l|l|l|l|}
\hline & Frequency & Percent & $\begin{array}{l}\text { Valid } \\
\text { Percent }\end{array}$ & $\begin{array}{l}\text { Cumulative } \\
\text { Percent }\end{array}$ \\
\hline Strongly Agree & 85 & 42.5 & 42.5 & 42.5 \\
Agree & 67 & 33.5 & 33.5 & 76.0 \\
Neutral & 6 & 3.0 & 3.0 & 79.0 \\
Valid & 28 & 14.0 & 14.0 & 93.0 \\
Disagree & 14 & 7.0 & 7.0 & 100.0 \\
Strongly & & & & \\
Disagree & 200 & 100.0 & 100.0 & \\
Total & &
\end{tabular}

The results obtained showed that role of work distribution was considered necessary when it comes to improving the quality of education in HEIs. The statement presented revealed positive responses because it showed 
that $42.5 \%$ strongly agree, $33.5 \%$ agree, $3 \%$ remained neutral, $14 \%$ disagreed and $7 \%$ strongly disagreed. The statements observed, therefore, show that it is necessary to focus on equal work distribution in educational institutes of Pakistan.

\section{Comparison of work distribution in educational institutes of China with Pakistan}

The results obtained highlight the fact that educational institutes of Pakistan in terms of work distribution are weak. If review of the work distribution in China was done, it has been observed by Yang (2019) and Guo, Huang and Zhang (2019) that it is quite strong. They investigated various departments of universities in China and reported that no work distribution issues were found. They also reported that salaries paid to management team members were quite high as compared to other educational institutes around the world. Zhang Bai and Qin (2018) wrote that some international management non-native team members $\theta$ working in educational institutes of China, were not paid as high as compared to the Chinese natives. However, no other study was found supporting or contradicting with this statement.

Mastoi and Saengkrod (2019) and Zhao, Beckett and Wang (2017) reported that a top-down structure was followed in most of the educational institutes of China. This allowed for better infrastructure and an increased balance of workload. Due to this reason, Wang, Whitehead and Bayes (2016) also supported the work distribution in China and argued that other nations can take it as a role model for them.

Based on the observations, this research accepts the below-given hypothesis:

H1 - Role of work distribution in improving quality education is low in Higher Educational Institutes (HEIs) of Pakistan as compared to China ACCEPTED

Access to digital library (second hypothesis)

The first statement

- The access to digital libraries in your Higher Educational Institutes is not provided. 
Table 4 Statement 4 results

Statement 4

\begin{tabular}{|c|c|c|c|c|c|}
\hline & & Frequency & Percent & $\begin{array}{l}\text { Valid } \\
\text { Percent }\end{array}$ & $\begin{array}{l}\text { Cumulative } \\
\text { Percent }\end{array}$ \\
\hline \multirow{6}{*}{ Valid } & Strongly Agree & 76 & 38.0 & 38.0 & 38.0 \\
\hline & Agree & 71 & 35.5 & 35.5 & 73.5 \\
\hline & Neutral & 7 & 3.5 & 3.5 & 77.0 \\
\hline & Disagree & 32 & 16.0 & 16.0 & 93.0 \\
\hline & $\begin{array}{l}\text { Strongly } \\
\text { Disagree }\end{array}$ & 14 & 7.0 & 7.0 & 100.0 \\
\hline & Total & 200 & 100.0 & 100.0 & \\
\hline
\end{tabular}

The results were not in favour of the educational institute, because most of the respondents did not have access to digital library. Out of the 200 students, $38 \%$ strongly agreed, $35.5 \%$ agreed, $3.5 \%$ remained neutral, $16 \%$ disagreed, and $7 \%$ strongly disagreed with the statement. Based on the observations made, it can be argued that access to digital library is not given to the students at least in the investigated educational institutes of Pakistan.

The second statement for carrying out the investigation of this hypothesis was:

- There is an important role of digital library access in improving quality education in educational institutes of Pakistan.

Table 5 Statement 5 results

Statement 5

\begin{tabular}{|l|l|l|l|l|}
\hline & Frequency & Percent & $\begin{array}{l}\text { Valid } \\
\text { Percent }\end{array}$ & $\begin{array}{l}\text { Cumulative } \\
\text { Percent }\end{array}$ \\
\hline Strongly Agree & 72 & 36.0 & 36.0 & 36.0 \\
Agree & 71 & 35.5 & 35.5 & 71.5 \\
Neutral & 7 & 3.5 & 3.5 & 75.0 \\
Valid & 34 & 17.0 & 17.0 & 92.0 \\
Disagree & 16 & 8.0 & 8.0 & 100.0 \\
Strongly & & & & \\
Disagree & 200 & 100.0 & 100.0 & \\
Total & &
\end{tabular}

The results obtained show that digital library access was considered the most necessary when it comes to analysing the quality of educational institutes. Out of the 200 respondents, $36 \%$ strongly agree, $35.5 \%$ agree, $3.5 \%$ remained neutral, $17 \%$ disagree and $8 \%$ strongly disagreed. Therefore, the 
students rated access to digital library as an important factor when elevating the quality of education.

The third statement included in the questionnaire was:

- It is considered necessary to provide digital library access in order to improve quality of education in HEIs.

Table 6 Statement 6 results

Statement 6

\begin{tabular}{|c|c|c|c|c|c|}
\hline & Frequency & Percent & $\begin{array}{l}\text { Valid } \\
\text { Percent }\end{array}$ & $\begin{array}{l}\text { Cumulative } \\
\text { Percent }\end{array}$ \\
\hline \multirow{6}{*}{ Valid } & Strongly Agree & 69 & 34.5 & 34.5 & 34.5 \\
\hline & Agree & 73 & 36.5 & 36.5 & 71.0 \\
\hline & Neutral & 5 & 2.5 & 2.5 & 73.5 \\
\hline & Disagree & 34 & 17.0 & 17.0 & 90.5 \\
\hline & $\begin{array}{l}\text { Strongly } \\
\text { Disagree }\end{array}$ & 19 & 9.5 & 9.5 & 100.0 \\
\hline & Total & 200 & 100.0 & 100.0 & \\
\hline
\end{tabular}

The results obtained show that more than half the students rated access to digital library as one of the necessary components for elevating quality of education. Most of the students said that it is necessary to include digital library access in educational institutes. In response to the statement, $34.5 \%$ strongly agree, $36.5 \%$ agree, $2.5 \%$ remained neutral, $17 \%$ disagreed, and $9.5 \%$ strongly disagreed. Therefore, the management needs to focus on the provision of new and improved digital library access for the students in order to remove barriers to quality education.

\section{Critical comparison of results with China}

If the above results are compared with China, various conclusions can be drawn. According to the results obtained the access to digital libraries in Pakistan is weak. While research from Liu, et al., (2019), reported that digital library access in China was available in more than $80 \%$ universities making it easier for students to access digital libraries at their homes. Supporting the statement, Bhayo et al., (2018) wrote that digital library access is available to all the students in various provinces of China except for a few new universities where developments are taking place. Hence it can be said that access to digital libraries in China is readily available, and in better format as compared to Pakistan.

If the role of digital libraries in China is evaluated and compared with Pakistan, it is argued by Gao et al., (2019) that digital libraries in China were mostly used for accessing course content from the websites, and not needing 
to consulting physical libraries. Zhou (2019) wrote that digital libraries in China were mostly to create research interests among the students and make their academic career hassle-free. But with an increase in digital libraries, students have started to avoid physical libraries and rate of students significantly decreased. Nonetheless, keeping that aside, the access to digital library in China is high as compared to Pakistan, which resulted in an increment in quality education. Therefore, it can be argued that performance of educational institutes in China is high as compared to Pakistan.

The results observed accepts the below-given hypothesis:

$\mathrm{H} 2$ - Access to digital library in improving quality education is low in Higher Educational Institutes (HEIs) of Pakistan as compared to Pakistan - ACCEPTED

Number of PhD faculty members in educational institutes of Pakistan $\left(3^{\text {rd }}\right.$ hypothesis)

This hypothesis was checked to evaluate whether number of $\mathrm{PhD}$ faculty members in educational institutes of Pakistan are present in adequate number and whether it contributes to the development of quality environment in the institutes. The first statement inquired by the respondents was:

- The number of PhD faculty in your Higher Educational Institutes is inadequate

Table 7 Statement 7 results

Statement 7

\begin{tabular}{|c|c|c|c|c|c|}
\hline & Frequency & Percent & $\begin{array}{l}\text { Valid } \\
\text { Percent }\end{array}$ & $\begin{array}{l}\text { Cumulative } \\
\text { Percent }\end{array}$ \\
\hline \multirow{6}{*}{ Valid } & Strongly Agree & 70 & 35.0 & 35.0 & 35.0 \\
\hline & Agree & 70 & 35.0 & 35.0 & 70.0 \\
\hline & Neutral & 4 & 2.0 & 2.0 & 72.0 \\
\hline & Disagree & 36 & 18.0 & 18.0 & 90.0 \\
\hline & Strongly & 20 & 10.0 & 10.0 & 100.0 \\
\hline & Disagree & $b 00$ & 1000 & 1000 & \\
\hline
\end{tabular}

$35 \%$ of the respondents strongly agreed with the statement that number of $\mathrm{PhD}$ faculty members in educational institute is inadequate. $35 \%$ strongly agree, $35 \%$ agree, $2 \%$ remained neutral, $18 \%$ disagreed, and $10 \%$ strongly disagreed with the statement. Hence, it can be said that number of $\mathrm{PhD}$ faculty in 4 investigated institutes is inadequate and contributing to low quality of the educational institute.

The second statement inquired of the respondents was: 
- There is an important role of $\mathrm{PhD}$ faculty member in improving quality education in educational institutes of Pakistan.

Table 8 Statement 8 results

\section{Statement 8}

\begin{tabular}{|c|c|c|c|c|c|}
\hline & & Frequency & Percent & $\begin{array}{l}\text { Valid } \\
\text { Percent }\end{array}$ & $\begin{array}{l}\text { Cumulative } \\
\text { Percent }\end{array}$ \\
\hline & Strongly Agree & 67 & 33.5 & 33.5 & 33.5 \\
\hline & Agree & 71 & 35.5 & 35.5 & 69.0 \\
\hline & Neutral & 5 & 2.5 & 2.5 & 71.5 \\
\hline Valid & Disagree & 34 & 17.0 & 17.0 & 88.5 \\
\hline & $\begin{array}{l}\text { Strongly } \\
\text { Disaoree }\end{array}$ & 23 & 11.5 & 11.5 & 100.0 \\
\hline & Total & 200 & 100.0 & 100.0 & \\
\hline
\end{tabular}

The results obtained show that $33.5 \%$ strongly agreed, $35.5 \%$ agreed, $2.5 \%$ remained neutral, $17 \%$ disagreed while $11.5 \%$ strongly disagreed with the statement. Based on the observations made, it can be said that there is an important role of $\mathrm{PhD}$ faculty in improving quality of education in educational institutes. However, the responses in the last statement show that number of $\mathrm{PhD}$ faculty is severely less in educational institutes.

The third statement of the questionnaire was:

- It is considered necessary to increase $\mathrm{PhD}$ faulty in order to improve quality of education in HEIs.

The answers were given in the following fashion:

Table 9 Statement 9 results

\section{Statement 9}

\begin{tabular}{|c|c|c|c|c|c|}
\hline & & Frequency & Percent & $\begin{array}{l}\text { Valid } \\
\text { Percent }\end{array}$ & $\begin{array}{l}\text { Cumulative } \\
\text { Percent }\end{array}$ \\
\hline \multirow{7}{*}{ Valid } & Strongly Agree & 70 & 35.0 & 35.0 & 35.0 \\
\hline & Agree & 68 & 34.0 & 34.0 & 69.0 \\
\hline & Neutral & 6 & 3.0 & 3.0 & 72.0 \\
\hline & Disagree & 33 & 16.5 & 16.5 & 88.5 \\
\hline & Strongly & 23 & 11.5 & 11.5 & 100.0 \\
\hline & Disagree & & & & \\
\hline & Total & 200 & 100.0 & 100.0 & \\
\hline
\end{tabular}


The results obtained show that $\mathrm{PhD}$ faculty members should be increased in educational institutes of Pakistan because it is rated necessary by the students. Out of 200 respondents, 35\% strongly agreed, 34\% agree, 6\% marked neutral, $16.5 \%$ disagree and $11.5 \%$ strongly disagree. Therefore, it can be argued that number of $\mathrm{PhD}$ faculty members should be increased by the management of each university.

\section{Critical comparison of number of $\mathrm{PhD}$ faculty members in China with Pakistan}

According to the findings of this investigation, a number of $\mathrm{PhD}$ faculty members in Pakistan were very low as reported by various respondents. Whilst in higher educational institutes of China, it has been observed that Zhou (2019) reported some positive findings. According to their results obtained, it has been observed that number of $\mathrm{PhD}$ faculty members in each university is at least $20 \%$ more as compared to Masters PhD. Supporting the results, Imran et al., (2019) wrote that China's higher education standards recently improved, and because of that reason, the management of educational institutes saw growth in research by $20 \%$ between 2015-2017. Based on the results obtained, it can be said that the quality of higher educational institutes in China is much higher as compared to Pakistan since the number of PhD faculty is significantly high.

It is believed that the quality of education cannot be improved without hiring of an adequate number of $\mathrm{PhD}$ faculty members. However, when the results obtained are compared with China, to what?, it has been reported by Ma (2020) that education quality in China is kept on top priority while hiring of PhD faculty members which are is not the case in Pakistan. Carrying out a survey in various educational institutes of China, Chen and Zhang (2018) reported that China is much better in hiring of $\mathrm{PhD}$ faculty from other nations and paying them well. Due to this reason, a major increment has been observed in the development of educational institutes in China along with research contributions.

Based on the results obtained, the following hypothesis is accepted in this research:

H3 - Number of PhD faculty members in educational institutes of Pakistan is low as compared to China and contributing to low quality among the educational institutes - ACCEPTED 


\section{Conclusion}

Quality of educational institutes depends on a number of factors, and the support they provide to their students for carrying out the management activities and increasing their interest in practical and theoretical learning. Out of many Quality Assurance Parameters, this research investigated three of them; equal work distribution, access to digital library and number of $\mathrm{PhD}$ faculty members. Based on the assessment of research questions, and hypotheses results, it can be argued that students studying in the four investigated institutes of Pakistan were not happy with work distribution, neither happy with number of $\mathrm{PhD}$ faculty nor provided with access to digital library. The survey results show that not many students supported the statement that work was distributed equally in their institute. A comparison with China showed that educational institutes were very strong in terms of work distribution in educational institutes. Most of them followed a top down hierarchy, and the salaries of management team members were very high.

The second hypothesis was to check whether students in Pakistan and China were provided with access to a digital library. A high majority of students in Pakistan argued that performance of educational institutes declined because access to digital library was not available in some institutes. Conversely,-HEIs in China ensured that student access to a digital library was compulsory and provided.

The third hypothesis and question were linked with the findings, whether the number of $\mathrm{PhD}$ faculty in investigated institutes was adequate and whether it was better than China. The results went against the institutes of Pakistan, because students said that their institute did not have an adequate number of PhD faculty. While scholars who investigated Chinese HEIs argued that PhD faculty members were high, and Masters students were low in these educational institutes. However, students in Pakistan said that educational institutes must be focusing on increasing number of $\mathrm{PhD}$ faculty members because it contributes to an increment of quality education platform. Overall, it can be concluded that educational institutes of Pakistan currently suffer from the problems of work distribution, providing access to digital library and hiring PhD faculty, which is why their quality of education is not as good as Chinese universities.

\section{Significance}

This research is unique because, when searched on internet no investigation was found performing comparison on these three parameters between China and Pakistan. Furthermore, this research provides some significant insights as to how quality of educational institutes can improve. The results will assist the university management of Pakistan to focus on their 
weaknesses, and ensure that quality assurance requirements followed in China are met.

\section{Limitations}

This study is limited to comparing two nations only which are China and Pakistan, and might or might not work for other countries. This study did not adopt quantitative methodology for investigation in China, which can decline reliability of results. In addition, sample size was small as compared to number of students studying in different universities of Pakistan.

\section{Acknowledgement}

I would like to acknowledge that this researcher was carried out be me, and I received a lot of support by the management, friends and my supervisor. I acknowledge that my parents also supported morally to carry out this research which helped me to complete this research within my targeted time.

\section{References:}

1. Ajmal, M. (2017). Implementation of Quality Assurance and Accreditation Policy in Open Distance Learning Teacher Education Programs in Pakistan. JOURNAL OF CONTEMPORARY TEACHER EDUCATION, 67, 1-9.

2. Aslam, M. I. (2016). Validation of the Higher Education Commission Quality Assurance Indicators used for Self-Assessment Mechanism at Universities in Punjab Province (Doctoral dissertation, University of the Punjab, Lahore).

3. Baig, S. A., Abrar, M., Ali, A., \& Ahmad, M. (2015). Implementation of TQM on higher education in Pakistan. Quality \& Quantity, 49(1), 51-56. https://doi.org/10.1007/s11135-013-9973-7

4. Bhayo, N. H., Yuyou, Q., Zeng, W., \& Dong, J. (2018). Role of District Education Officials in Quality Education in Nanguan and Shikarpur Districts: A Comparative Study Between China and Pakistan. language, 9(26).

5. Chen, Y., \& Zhang, F. (2018). Fiscal Expenditure and Education Quality in China: A Regional Heterogeneity Analysis. European Journal of Marketing and Economics, 1(3), 44-52. https://dx.doi.org/10.26417/ejme.v1i3.p44-52

6. Gao, P., Song, Y., Li, X., \& Lin, H. (2019, August). Quality Guarantee of Graduate Education in China: A Bibliometric Study. In 2019 5th International Conference on Social Science and Higher Education (ICSSHE 2019). Atlantis Press. https://dx.doi.org/10.2991/icsshe19.2019.226 
7. Guo, L., Huang, J., \& Zhang, Y. (2019). Education Development in China: Education Return, Quality, and Equity. Sustainability, 11(13), 3750. https://doi.org/10.3390/su11133750

8. Hazelkorn, E., Coates, H., \& McCormick, A. C. (Eds.). (2018). Research handbook on quality, performance and accountability in higher education. Edward Elgar Publishing.

9. Herani, G. M., Mugheri, M. S., \& Advani, A. (2015). Measuring the endeavors' Impact of Quality Enhancement Cell on Quality of Higher Education system in Pakistan. A case of Private and Public Universities in Pakistan. Journal of Management for Global Sustainable Development, 1(1), 37-39.

10. Hina, K., \& Ajmal, M. (2016). Quality Assurance and Enhancement Mechanism in Tertiary Education of Pakistan: Recent Status, Issues and Expectations. Pakistan Journal of Education,33(1), 1-11. http://dx.doi.org/10.30971/pje.v33i1.13

11. Imran, M., Omar, T. K., Allah, A. A. F., \& El All, W. A. A. (2019). The Impact of Higher Education Quality on Student's Satisfaction: Empirical Evidence from PR China. Pacific International Journal, 2(1), 26-35.

12. John, P., \& Fanghanel, J. (Eds.). (2015). Dimensions of marketisation in higher education. Routledge.

13. Khan, F. U., \& Kamran, A. (2017, July). Impact of Management Information Systems Techniques on Quality Enhancement Cell's Report for Higher Education Commission of Pakistan. In International Conference on Management Science and Engineering Management (pp. 367-381). Springer, Cham. https://doi.org/10.1007/978-3-319-59280-0_30

14. Kumar, R. (2019). Research methodology: A step-by-step guide for beginners. Sage Publications Limited.

15. Liu, X., Hu, B., \& Huang, J. H. (2019). The Quality of Play Center Activities of Early Childhood Education in China. English Language Teaching, 12(8), 95-105.

16. Ma, J. (2020). Research on Higher Education Quality Assurance in China During the Popularization. Higher Education Research, 5(1), 1. https://doi.org/10.11648/j.her.20200501.11

17. Mastoi, A. G., \& Saengkrod, L. X. W. (2019). Higher Education Service Quality based on Students' Satisfaction in People's Republic of China. Higher Education, 10(6). https://doi.org/10.7176/jep\%2F10-6-15

18. Mohsin, M. S., Mohsin, M. N., \& Rasheed, M. (2016). ANALYSIS OF HEC QUALITY ASSURANCE MEASURES IN HIGHER EDUCATION INSTITUTIONS OF THE PUNJAB: IMPLICATION 
FOR TERTIARY EDUCATION IN AGRICULTURE AND PROFESSIONAL DISCIPLINES. Journal of Agricultural Research (03681157), 54(3), 12-19.

19. Pornphol, P., \& Chittayasothorn, S. (2017). A Case-Based Quality Assurance System for Higher Education. International Journal of Culture and History, 3(1), 7-11. https://doi.org/ 10.18178/ijch.2017.3.1.073

20. Shabbir, M., Khalid, M. I., Bakhsh, K., Mohsin, M. N., Rasool, S., \& Mohsin, M. S. (2016). Improving Professional Development System through Quality Assurance Practices in the Universities of Pakistan. International Education Studies, 9(1), 141-147.

21. Shahid, H., Wahab, Z., \& Ahmed, S. A. (2016). Factor Analysis to Explore the Indicators of Quality Assurance Mechanism on Higher Educational Institutions in Pakistan. Journal of Basic and Applied Sciences, 12, 146-154.

22. Shaikh, S., Memon, Z. A., \& Shah, A. A. (2017). Adoption and impact of quality assurance processes in higher education institutions of Jamshoro Education City. Grassroots, 50(3), 1-9.

23. Subhani, M. I., Osman, A., \& Niaz, M. I. (2017). ROLE OF HIGHER EDUCATION COMMISSION (HEC) IN PROMOTING RESEARCH OUTPUT IN PAKISTAN. The EUrASEANs: journal on global socio-economic dynamics, 3 (4), 93-100. https://doi.org/10.35678

24. Sukdee, T., Tornee, S., \& Kraipetch, C. (2017). Factor Analysis of Key Success Indicators in Curriculum Quality Assurance Operation for Bachelor's Degree in Physical Education. International Journal of Higher Education, 6(3), 109-115.

25. Viraiyan, T., Kamalanabhan, T. J., \& Keshwar, S. A. (2016). An analysis of higher education service quality in Mauritius using HESQUAL. International Journal of Business Research, 16(2), 89104. dx.doi.org/10.18374/IJBR-16-2.7

26. Wang, C. C., Whitehead, L., \& Bayes, S. (2016). Nursing education in China: Meeting the global demand for quality healthcare. International journal of nursing sciences, 3(1), 131-136. https://doi.org/10.1016/j.ijnss.2016.02.009

27. Yang, L. (2019, April). The Value Orientation System Construction and Development Direction of Higher Education Quality Assurance in China. In 1st International Symposium on Education, Culture and Social Sciences (ECSS 2019). Atlantis Press. https://dx.doi.org/10.2991/ecss-19.2019.36

28. Ying, S., \& Yan, L. (2018). THE UTILIZATION OF INFORMATION TECHNOLOGY IN HIGHER EDUCATION 
QUALITY ASSURANCE IN CHINA. In Capacity Building for Next Generation Quality Assurance in Higher Education (pp. 94-98).

29. Zhang, L. N., Bai, D. Q., \& Qin, J. (2018, May). An Investigation into Policies to Improve the Quality of Basic Education in China-------A Case Study of No. 128 Middle School in Shenyang City. In 4th Annual International Conference on Management, Economics and Social Development (ICMESD 2018). Atlantis Press. https://dx.doi.org/10.2991/icmesd-18.2018.81

30. Zhao, J., Beckett, G. H., \& Wang, L. L. (2017). Evaluating the research quality of education journals in China: Implications for increasing global impact in peripheral countries. Review of Educational Research, 87(3), 583-618. https://doi.org/10.3102\%2F0034654317690813

31. Zhou, T. (2019). Drama Education Differences Between China and Western Countries. Asian Education Studies, 4(2), 30. https://doi.org/10.20849/aes.v4i2.657 